\title{
ADAPTABILITY AND STABILITY OF COWPEA GENOTYPES VIA REML/BLUP AND GGE BIPLOT
}

\author{
ADAPTABILIDADE E ESTABILIDADE DE GENÓTIPOS DE FEIJÃO-CAUPI VIA \\ REML/BLUP E GGE-BIPLOT
}

\section{Hadassa Kathyuci Antunes de ABREU'1; Gessi CECCON'; Agenor Martinho CORREA²; Ricardo FACHINELLI'; Euriann Lopes Marques YAMAMOTO'; Paulo Eduardo TEODORO 3}

1. Universidade Federal da Grande Dourados - UFGD, Dourados, MS, Brasil; 2. Universidade Estadual de Mato Grosso do Sul-UEMS, Aquidauana, MS, Brasil; 3. Universidade Federal de Mato Grosso do Sul-UFMS, Chapadão do Sul, MS, Brasil.

eduteodoro@hotmail.com

\begin{abstract}
Several methodologies have been proposed in order to measure the influence that genotype-by-environment interaction exerts on the various characters of interest. The mixed models using REML/BLUP and GGE Biplot have been mentioned as advantageous to identify superior genotypes. The use of environmental information can be useful to find the factors that are in the real difference between the genotypes. The objective of this study was to compare statistical methodologies for the adaptability and stability analysis of cowpea genotypes in value for cultivation and use testings. The experiments were carried out from March to July 2016 and 2017, in the municipalities of Dourados and Aquidauana. A randomized complete block design was used, with 14 genotypes and four replicates, 12 advanced lines and two commercial cultivars. After detecting significant genotype-by-environment interaction, the adaptability and phenotypic stability of cowpea genotypes were analyzed by the GGE Biplot and REML/BLUP. Both methodologies were concordant in the identification of the best cowpea genotypes for the State of Mato Grosso do Sul. The genotypes 6 (Pingo-de-ouro 1-5-4), 10 (Pingo-de-ouro 1-5-10) and 8 (Pingo-de-ouro 1-5-7) are the most suitable to be grown in the State, because they have gathered high grain yield, adaptability and stability.
\end{abstract} models.

KEYWORDS: Vigna unguiculat., Genotypes $\times$ environments interaction. Multivariate analysis. Mixed

\section{INTRODUCTION}

Cowpea (Vigna unguiculata (L.) Walp.) is an important source of protein for the Brazilian population, mainly for low-income people in the North and Northeast regions, where it is also an important factor for generating employment and income (CARDOSO et al., 2014; PEREIRA et al., 2014). Currently, its consumption is expanding more intensely to the Midwest and Southeast regions of Brazil, where it has been cultivated in large areas using technology and standing out as an alternative to farming arrangements, especially in the off-season growing (RODRIGUES et al., 2017). This fact contributes to the genotype-by-environment interaction (GxE), i.e., the best genotype in one place does not maintain its performance in other environments (OLIVEIRA et al., 2018).

Knowledge of the GxE interaction is important for breeders, since it allows to safely recommend new genotypes. The study of GxE interaction requires that several genotypes are evaluated in different environments, such as sites, seasons and years. In cowpea breeding programs, a large number of genotypes are tested annually before their final recommendation and multiplication, and the GxE interaction study is performed at the final stages of the program (SANTOS et al., 2014). The alternative for reducing the influence of GxE interaction is choicing varieties with wide adaptability and good stability. In this context, there are recent methodologies that adequately explain the main effects (genotypes and environments), among which stand out the GGE-Biplot and REML/BLUP methodologies (SILVA et al., 2011).

The GGE-Biplot (Genotype and Genotype by Environments Interaction) methodology seeks to cluster the genotype effect with the interaction, multiplicative effect and to submit these effects to principal component analysis, known as sites regression (SREG), as suggested by Cornelius et al. (1996) and Crossa and Cornelius (1997). GGEBiplot analysis was adopted as a graph able to interpret the GxE interaction in the SREG model (YAN, et al., 2000). The method considers that the primary environmental effect is not relevant for selecting genotypes $(\mathrm{G})$, and hence the $\mathrm{G}$ effect is given as a multiplicative effect of GxE interaction. This technique integrates analysis of variance with principal components analysis and exposes superior 
efficiency by explaining the largest proportion of the sum of squares for the interaction when compared to the joint analysis of variance.

Restricted maximum likelihood/best linear unbiased predictor (REML/BLUP) is based on the assumptions that the lower the standard deviation of genotype behavior across the sites, the higher the harmonic mean of its genotypic values across the sites. Moreover, it generates results on the unit or scale of the evaluated trait that can be interpreted directly as genetic values, which other methods do not provide. Thus, the simultaneous selection for yield, stability and adaptability can be applied in the context of mixed models by the method of harmonic mean of the relative performance of predicted genetic values (MHPRVG) (SILVA et al., 2011; ROSADO et al. 2012).

Currently, the GGE-Biplot and REML/BLUP methods have been used separately to investigate the GxE interaction in several crops involving carrot, maize and cowpea production, reported in studies carried out by Silva et al. (2011), Martinelli (2013) and Santos et al (2016), respectively, but there are still few reports of its use in cowpea. The authors verified that these methodologies can be used in a complementary way in the recommendation of genotypes.

The objective of this study was to verify the association between the GGE-Biplot and REML/BLUP methods in the selection of cowpea genotypes simultaneously gathering high grain yield, adaptability and stability to environments in the State of Mato Grosso do Sul.

\section{MATERIAL AND METHODS}

\section{Deployment and conduction of the trials}

Three trials were deployed for evaluating 14 genotypes of erect and semi-erect cowpea (12 lines and two cultivars from the Embrapa Meio-Norte cowpea breeding program). The relevant information about them is available in Table 1. The two commercial cultivars used as controls were selected because they presented favorable characteristics. The cultivar BRS-Tumucumaque (13) has an architecture that allows the mechanized harvesting, white and medium-size grains and of great commercial acceptance, besides high grain yield and early cycle. The cultivar BRS Imponente (14) has extra-large and white grains, erect size, good resistance to lodging, high grain yield and it is recommended for dry farming.

Table 1. Genotypes evaluated in the VCU trials between the years 2016 and 2017, with their respective numbers of treatments, cultivar/lines and commercial subclasses.

\begin{tabular}{cccc}
\hline ID & Genotype & Cultivar/Line & Commercial subclass $^{(1)}$ \\
\hline 01 & Bico-de-ouro 1-5-11 & Line & SV \\
02 & Bico-de-ouro 1-5-15 & Line & SV \\
03 & Bico-de-ouro 1-5-19 & Line & SV \\
04 & Bico-de-ouro 1-5-24 & Line & ML \\
05 & Pingo-de-ouro 1-5-26 & Line & ML \\
06 & Pingo-de-ouro 1-5-4 & Line & ML \\
07 & Pingo-de-ouro 1-5-5 & Line & ML \\
08 & Pingo-de-ouro 1-5-7 & Line & ML \\
09 & Pingo-de-ouro 1-5-8 & Line & ML \\
10 & Pingo-de-ouro 1-5-10 & Line & ML \\
11 & Pingo-de-ouro 1-5-11 & Line & ML \\
12 & Pingo-de-ouro 1-5-14 & Line & ML \\
13 & BRS Tumucumaque & Cultivar & BR \\
14 & BRS Imponente & Cultivar & BC \\
\hline
\end{tabular}

ID: genotype identification. ${ }^{(1)}$ BR - Branco ; BC - Brancão ; ML - Mulato ; SV - Sempre-verde

Grain yield was evaluated $\left(\mathrm{kg} \mathrm{ha}^{-1}\right)$ in Value for Cultivation and Use Testing (VCU), carried out from March to August 2016 and 2017, in the municipalities of Dourados and Aquidauana, State of Mato Grosso do Sul. The experiments in Dourados were carried out in the years 2016 and 2017, and in Aquidauana only in 2017, totaling three environments, whose edafoclimatic characteristics are expressed in Table 2. The climate of the two sites is classified as Am and Aw according to Köppen. The soil chemical properties of each site in each harvest, performed at a depth from 0 to $20 \mathrm{~cm}$, are shown in Table 3 . Average temperature and accumulated rainfall over the crop development is shown in Figure 1. 
Table 2. Soil and climate characteristics of each site evaluated.

\begin{tabular}{ccccccccc}
\hline \multirow{2}{*}{ Site } & Year & Site & Latitude & Longitude & Altitude $(\mathrm{m})$ & Biome & Soil $^{1}$ & Climate $^{2}$ \\
\hline E1 & 2016 & Dourados & $20^{\circ} 03^{\prime} \mathrm{S}$ & $55^{\circ} 05^{\prime} \mathrm{W}$ & 407 & Atlantic Forest & Ferralsol & Am \\
E2 & 2017 & Dourados & $20^{\circ} 03^{\prime} \mathrm{S}$ & $55^{\circ} 05^{\prime} \mathrm{W}$ & 407 & Atlantic Forest & Ferralsol & Am \\
E3 & 2017 & Aquidauana & $22^{\circ} 01^{\prime} \mathrm{S}$ & $54^{\circ} 05^{\prime} \mathrm{W}$ & 174 & Pantanal & Haplic Acrisol & Aw \\
\hline
\end{tabular}

${ }^{1}$ According to WRB/FAO; ${ }^{2}$ According to Köppen classification.

Table 3. Chemical analysis of the soil sample from the different environments.

\begin{tabular}{lcccccccccc}
\hline Site/Year & $\begin{array}{c}\mathrm{pH} \\
\mathrm{CaCl}\end{array}$ & $\begin{array}{c}\mathrm{P} \\
\mathrm{mg} \mathrm{dm}^{-3}\end{array}$ & $\mathrm{~K}$ & $\begin{array}{c}\mathrm{Ca} \\
\mathrm{cmol}^{2}\end{array}$ & $\begin{array}{c}\mathrm{Mg} \\
\mathrm{dm}^{-3}\end{array}$ & $\mathrm{Al}$ & $\mathrm{H}+\mathrm{Al}$ & $\mathrm{SB}$ & $\begin{array}{c}\mathrm{CEC} \\
\mathrm{pH} \mathrm{7.0}\end{array}$ & $\mathrm{V} \%$ \\
\hline Dourados/2016 & 5.4 & 42 & 0.6 & 5.4 & 1.8 & 0.0 & 4.3 & 8 & 12 & 64 \\
Aquidauana/2017 & 5.12 & 32.10 & 0.72 & 3.50 & 0.76 & 0.00 & 3.19 & 4.98 & 8.18 & 60.97 \\
\hline
\end{tabular}

$\mathrm{pH}$ : Hydrogen Potential; SB: sum of bases; CEC: cation exchange capacity; V\%: Base saturation.

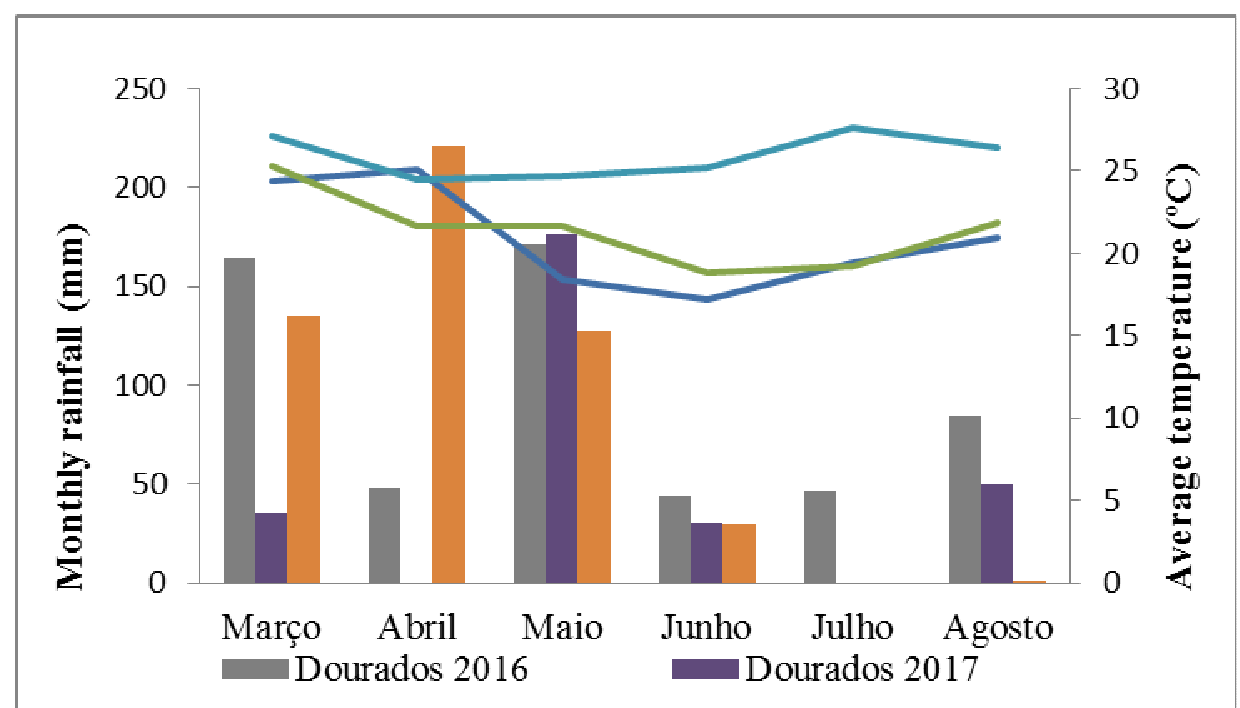

Figure 1. Rainfall profile and average temperature variation from 2016 to 2017 in Dourados, MS and Aquidauana, MS, during the period of conduction of the trials. Source: CEMTEC (Center for Monitoring Weather, Climate and Water Resources of Mato Grosso do Sul), 2017.

The experimental design was randomized blocks, with 14 treatments and four replicates. The experimental plot consisted of four rows with $5 \mathrm{~m}$ of length, spaced $0.50 \mathrm{~m}$, considering the two central rows as useful area. The experiments were carried out in March and April, while the harvest was carried out in July and August, respectively, in Dourados and Aquidauana. In Dourados the notillage system was adopted, while in Aquidauana the tillage system was used, consisting of harrowing and opening of the grooves for manual seeding. This sowing scheduling aimed to homogenize the climatic conditions, considering the particularities of each municipality. One week after seedlings emergence, manual thinning leaving eight seedlings per meter was performed. In all years and sites, no sowing and cover fertilization were performed. Pest control was carried out with the application of
Chlorpyrifos $(480 \mathrm{~g} / \mathrm{L})$ insecticide at a rate of 0.6 $\mathrm{L} / \mathrm{ha}$ of the commercial product. No fungicide application via foliar or seed was performed in both years and sites. Harvesting of the pods was performed manually in all years and sites.

\section{Statistical and genetic analysis}

The statistical procedures consisted of analysis of variance for each environment, followed by a joint analysis of variance of trials in the environments, according to the model proposed by Cruz et al. (2006) described in Equation 1:

$Y_{i j k}=\mu+B / E_{j k}+G_{i}+E_{j}+G E_{i j}+e_{i j k}$

where: $Y_{\mathrm{ijk}}$ is the observation in the $\mathrm{k}$-th block, evaluated in the i-th genotype and j-th environment; $\mu$ is the overall mean of the experiments; $\mathrm{B} / \mathrm{E}_{\mathrm{jk}}$ is the effect of block $\mathrm{k}$ within environment $j ; G_{i}$ is the effect of the $i$-th genotype, 
considered as fixed; $E_{j}$ is the effect of the $j$-th environment, considered as random; $\mathrm{GxE}_{\mathrm{ij}}$ is the random effect of the genotype $i \mathrm{x}$ environment $\mathrm{j}$ interaction; $e_{i j k}$ is the random error associated with the observation $\mathrm{Y}_{\mathrm{ijk}}$.

The adaptability and stability parameters of the cowpea genotypes were estimated by the GGEBiplot and REML/BLUP method by using the software R (R Development Core Team 2014) and Selegen (Resende 2007), respectively. The GGE biplot method was employed, according to Equation 2:

$$
\mathrm{Y}_{\mathrm{ij}}-\mathrm{y}_{\mathrm{j}}=\lambda_{1} \alpha_{\mathrm{i} 1} \beta_{\mathrm{j} 1}+\lambda_{2} \alpha_{\mathrm{i} 2} \beta_{\mathrm{j} 2}+\varepsilon_{\mathrm{ij}}
$$

where: $Y_{i j}$ represents the mean yield of genotype $i$ in environment $j ; y_{j}$ is the overall mean of genotypes in environment $\mathrm{j} ; \lambda_{1}$ and $\lambda_{2}$ are the singular values of the first and second principal components, respectively; $\alpha_{i 1}$ and $\alpha_{i 2}$ are the first two eigenvectors for the $\mathrm{i}$-th genotype; $\beta_{\mathrm{j} 1}$ and $\beta_{\mathrm{j} 2}$ are the first two eigenvectors for the $\mathrm{j}$-th environment; and $\varepsilon_{\mathrm{ij}}$ is the error associated with the two-dimensional model, i.e., the percentage of the effects of $\mathrm{G}+\mathrm{GxE}$ not explained by the first two principal components. For the graphs constructed with GGE biplot method, the parameters $\mathrm{SVP}=2$; data centering $=2$; data scaling $=0$; transformation $=0$, as performed by Silva et al., (2011), Martinelli (2013) and Santos et al (2016).
For the REML / BLUP analysis the following statistical model was used for genetic evaluation by the highest values of the harmonic mean of the genotypic values: $\mathrm{Y}=\mathrm{Xr}+\mathrm{Zg}+\mathrm{Wi}+$ $\varepsilon$. In that: $\mathrm{Y}$ is the data vector, $\mathrm{r}$ is the vector of the effects of the repetition-environment combinations added to the general mean, $g$ is the vector of the genotypic effects, $i$ is the vector of the effects of the interaction GE, being $\varepsilon$ the vector of errors. Capital letters represent the incidence matrices for these effects.

\section{RESULTS AND DISCUSSION}

The results of the individual analysis of variance for the three environments are shown in Table 4. There are genetic variability among genotypes and homogeneity of the variances for the environments E1 (Dourados, 2016) and E3 (Aquidauana, 2017). The heteroscedasticity of the variances, as well as the residual correlation exposed by the data, is expected when there is a set of environments evaluated ranging in both spatial and temporal aspects. In this case, before proceeding the joint analysis, the Box-Cox transformation was applied to the grain yield values aiming at reducing the heteroscedasticity.

Table 4. Summary of the individual analysis of variance for grain yield $\left(\mathrm{kg} \mathrm{ha}^{-1}\right)$ of 14 cowpea genotypes evaluated in E1 (Dourados, 2016), E2 (Dourados, 2017) and E3 (Aquidauana, 2017).

\begin{tabular}{lcccc}
\hline SV & DF & E1 & E2 & E3 \\
\hline Block & 3 & $324983^{* * *}$ & $110483^{\mathrm{NS}}$ & $754^{\mathrm{NS}}$ \\
Genotype (G) & 13 & $123672^{* *}$ & $134036^{\mathrm{NS}}$ & $33865^{* * *}$ \\
Error & 39 & 37496 & 114276 & 9151 \\
Mean & & 483.88 & 974.02 & 601.69 \\
CV\% & & 40.01 & 34.70 & 15.89 \\
\hline
\end{tabular}

SV: sources of variation; DF: degrees of freedom; CV: Coefficient of variation; NS: not significant; ** and ***: significant at 1 and $0.1 \%$ probability level by $\mathrm{F}$ test, respectively.

It is possible to observe an oscillation of the coefficients of individual variation from $15.89 \%$ to $40.01 \%$, showing the influence of non-controllable causes on grain yield, possibly due to this trait does not present simple inheritance, and hence it is greatly influenced by environment. The joint analysis of variance was applied to the genotypes (Table 5), bringing together the two sites and the years. The GxE interaction was significant, resembling several surveys conducted with cowpea in Brazil (BARROSO et al., 2016; SANTOS et al., 2016; TORRES et al., 2016; TEODORO et al., 2015). After observing significant GxE interaction, the parameters of the adaptability and the phenotypic stability of the genotypes were estimated by the GGE-Biplot and REML/BLUP. The coefficient of variation of the joint analysis was $11.14 \%$, which demonstrates good experimental precision of the trials set. Silva et al. (2011) and Martinelli (2013) reported similar results when evaluating carrot and maize growing, respectively. 
Table 5. Summary of the joint analysis of variance for grain yield $\left(\mathrm{kg} \mathrm{ha}^{-1}\right)$ of 14 cowpea genotypes evaluated in 3 environments, in the 2016/2017 harvest.

\begin{tabular}{lcccc}
\hline SV & DF & MS & F & Pr>F \\
\hline Genotype (G) & 13 & 3.55 & 3.480 & $0.000129^{* * *}$ \\
Environment (E) & 2 & 68.11 & 5.373 & $0.001648^{* *}$ \\
Block x E & 9 & 3.89 & 66.770 & $<2 \mathrm{e}-16^{* * *}$ \\
G x E & 26 & 1.76 & 1.721 & $0.026214^{*}$ \\
Error & 117 & 0.91 & & \\
CV\% & & 11.14 & & \\
\hline
\end{tabular}

SV: sources of variation; DF: degrees of freedom; CV: Coefficient of variation; *,** and ***: significant at 5,1 and $0.1 \%$ probability level by $\mathrm{F}$ test, respectively.

\section{Adaptability and stability via GGE-Biplot}

In the GGE-Biplot methodology, it was verified that the first two principal components (PCA1 and PCA2), expressed the respective values of $64.63 \%$ and $24.79 \%$, derived from the decomposition of the singular values of the genotype $(\mathrm{G})+$ interaction effects $(\mathrm{GxE})$. The first principal component (PCA1) indicates the adaptability of the genotypes, which is highly correlated with yield, the second principal component (PC2) indicates stability, i.e, the genotypes closest to zero are the most stable (YAN et al. 2000).

In the origin of the Biplot center, there is a straight line for the placement of an environment or genotype called "environment vector" or "genotype vector", so that from these vectors, the specific interactions among a genotype and an environment can be visualized. The vectors from the Biplot center $(0 ; 0)$ divided the graph into seven sectors. By evaluating the yield of cowpea genotypes via GGE-Biplot, Santos et al. (2016) found a division of the graphs into five sectors, a result close to obtained here.

GGE-Biplot graph model shown in Figure 2 is known as "which-won-where". It presents the formation of a polygon to determine the best genotypes in each environment, this is due to the interconnection of the genotypes that are at the extreme points of the graph and their respective perpendicular lines (YAN; KANG, 2003; YAN; TINKER, 2006). The vertices of the polygon were formed by the genotypes: 12 (Pingo-de-ouro 1-514), 6 (Pingo-de-ouro 1-5-4), 10 (Pingo-de-ouro 15-10), 9 (Pingo-de-ouro 1-5-8) and 14 (BRS Imponente). The polygon presents the best cultivar for each environment and divides the environments and groups (ALWALA et al., 2010). The three environments were cut in 3 groups by the lines that left the center of origin of the Biplot. The genotypes that are located within the same sector are the most adapted to that sector environment. The genotypes13 (BRS Tumucumaque) and 12 (Pingode-ouro 1-5-14) were allocated in the group 1 . The genotypes 2 (Bico-de-ouro 1-5-15), 8 (Pingo-deouro 1-5-7) and 6 (Pingo-de-ouro 1-5-4) were allocated in the group 2. The group 3 allocated only the genotype 10 (Pingo-de-ouro 1-5-10). Thus, the winning genotypes were 12,6 and 10 , which are in the vertices of the sectors of the environments E3 (Aquidauana, 2017), E1 (Dourados, 2016) and E2 (Dourados, 2017) respectively. Thus, we can consider these genotypes as the most adapted to these environments.

There are no environments in the sectors where the genotypes 1 (Bico-de-ouro 1-5-11), 3 (Bico-de-ouro 1-5-19), 4 (Bico-de-ouro 1-5-24), 5 (Pingo-de-ouro 1-5-26), 7 (Pingo-de-ouro 1-5-5), 9 (Pingo-de-ouro 1-5-8), 11 (Pingo-de-ouro 1-5-11) and 14 (BRS Imponente) are allocated. This means that these genotypes are not productive in any environment, i.e., these genotypes are the worst regarding the grain yield in some or all environments. Hence the genotypes 2 (Bico-de-ouro 1-5-15), 6 (Pingo-de-ouro 1-5-4), 8 (Pingo-de-ouro 1-5-7), 10 (Pingo-de-ouro 1-5-10), 12 (Pingo-deouro 1-5-14) and 13 (BRS Tumucumaque) have some specific adaptation, and a careful evaluation is needed in order to get better recommendations. When genotypes give rise to polygon vertices, but do not contain any clustered environment, they are considered unfavorable to groups of tested environments, showing low grain yield (KARIMIZADEH et al. 2013). 


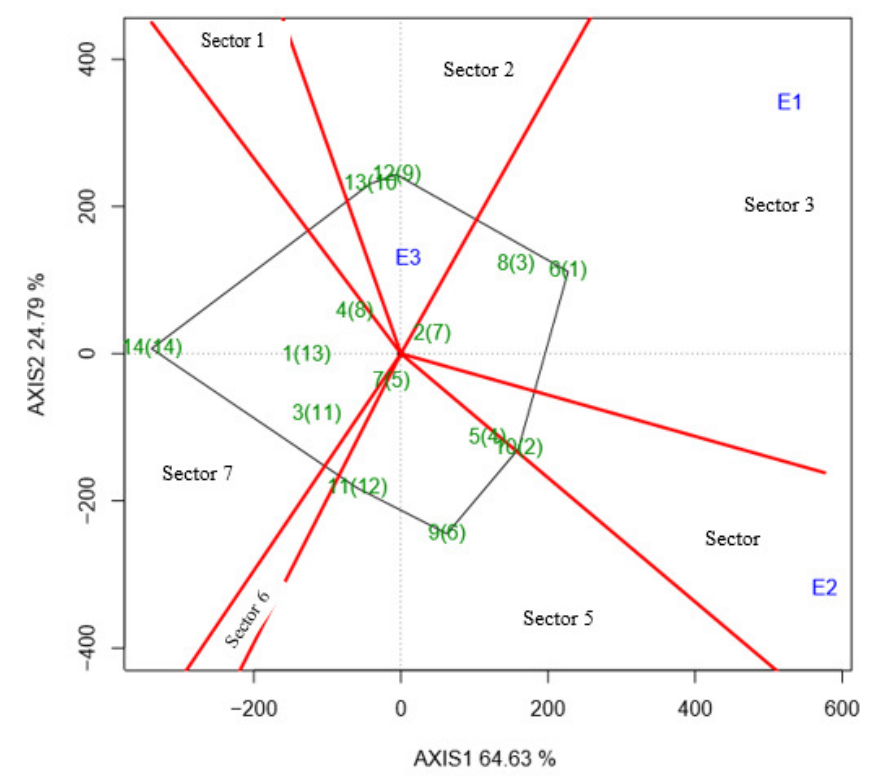

Figure 2. GGE-Biplot graph ("which-won-where") for grain yield of cowpea genotypes, performance of the best genotype in the environment $\left(\mathrm{kg} / \mathrm{ha}^{-1}\right) . *\left(\mathrm{n}^{\mathrm{o}}\right)$ represents the cowpea yield ranking

By analyzing Figure 3, where PC1 was $64.63 \%$ and PC2 $24.79 \%$, explaining $89.42 \%$ of the data dispersion, which meets the minimum limit of $80 \%$ recommended by Cruz et al. (2006), it is possible to predict which genotypes are more stable depending on the $\mathrm{PC} 1$ and $\mathrm{PC} 2$ values. The visualization of GGE-Biplot "mean versus stability" is presented in Figure 3. This an effective tool for the evaluation of genotypes in both yield and stability aspects (YAN et al., 2007; YAN, 2011).
The graph contains an MEA line of green color with an arrow on the $\mathrm{x}$ axis, indicating that the farther from the center $(0)$ of the Biplot the higher the yield and the smaller the yield. The other line with the same color on the y axis, without an arrow, indicates that the further away from the center (0) of the Biplot in both directions the lower the stability and the higher the genotype contribution to GxE interaction (GABRIEL, 1971; YAN; KANG, 2003).

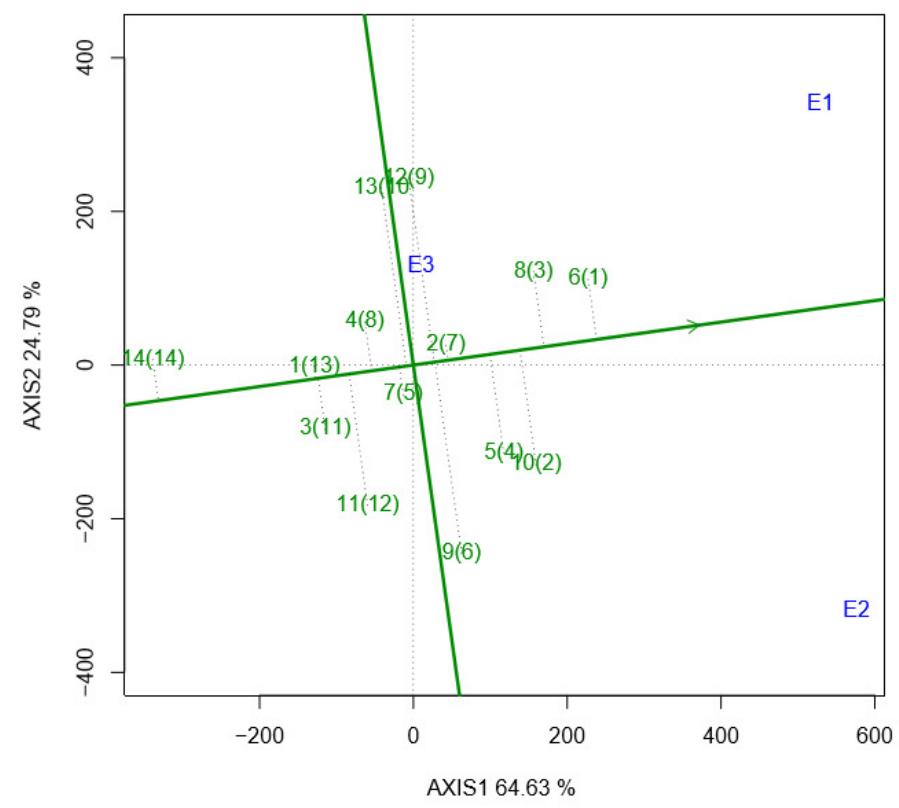

Figure 3. GGE-Biplot graph ("mean versus stability") with the medium-environment axis (MEA) for the grain yield of cowpea genotypes. ${ }^{*}\left(\mathrm{n}^{\circ}\right)$ represents the cowpea yield ranking. 
The second principal component (PC2) indicates stability, the genotype closer to zero is the most stable (YAN et al., 2000). In this context, it can be observed that genotype 2 (Bico-de-ouro- 1-5$15)$ is highly stable and its performance is above average. However, tYan (2011) and Yan and Tinker (2006) reported that "High stability" is desired only when it presents a high average performance. Then the best performance above the yield average and more stable was for the genotype 6 (Pingo-de-ouro 1-5-4), with a yield higher than genotype 2 (Bicode-ouro 1-5-15) but showing to be less stable. Despite the genotypes 1 (Bico-de-ouro 1-5-11) and 7 (Pingo-de-ouro 1-5-5) be considered stable, they had below-average yield and did not fit into ideal genotypes.

Thus, we can identify the genotypes 9 (Pingo-de-ouro 1-5-8) and 12 (Pingo-de-ouro 1-514) as the most unstable among those with aboveaverage yield. According to them average yield, the genotypes were classified in the following order: 6 (Pingo-de-ouro 1-5-4) > 10 (Pingo-de-ouro 1-5-10)> 8 (Pingo-de-ouro 1-5-7) $>5$ (Pingo-de-ouro 1-526) $>7$ (Pingo-de-ouro 1-5-5) $>9$ (Pingo-de-ouro 1-
5-8) $>2$ (Bico-de-ouro 1-5-15) $>4$ (Bico-de-ouro 1-524)> 12 (Pingo-de-ouro 1-5-14)> 13 (BRS Tumucumaque) $>3$ (Bico-de-ouro 1-5-19) $>11$ (Pingo-de-ouro 1-5-11)> 1 (Bico-de-ouro 1-5-11)> 14 (BRS Imponente). The genotypes 13 (BRS Tumucumaque) and 11 (Pingo-de-ouro 1-5-11), in addition to below-average yield, they were highly unstable and should be discarded from the point of view of grain yield.

In Figure 4 is shown the "ideal genotype" GGE-Biplot graph, as defined by Yan e Kang (2003), which makes it possible to make inferences about the ideal genotype. Of the fourteen genotypes evaluated, the genotype 6 (Pingo-de-ouro 1-5-4) is the one closest to the ideal, followed by the genotype 8 (Pingo-de-ouro 1-5-7). The genotypes 2 (Bico-de-ouro 1-5-15), 5 (Pingo-de-ouro 1-5-26) and 10 (Pingo-de-ouro 1-5-10) showed aboveaverage grain yield and behaved as stable, except genotype 10 (Pingo-de-ouro 1-5-10). It is observed in Figure 4 that genotype 14 (BRS Imponente) remained the worst performance and is the furthest from the ideal genotype.

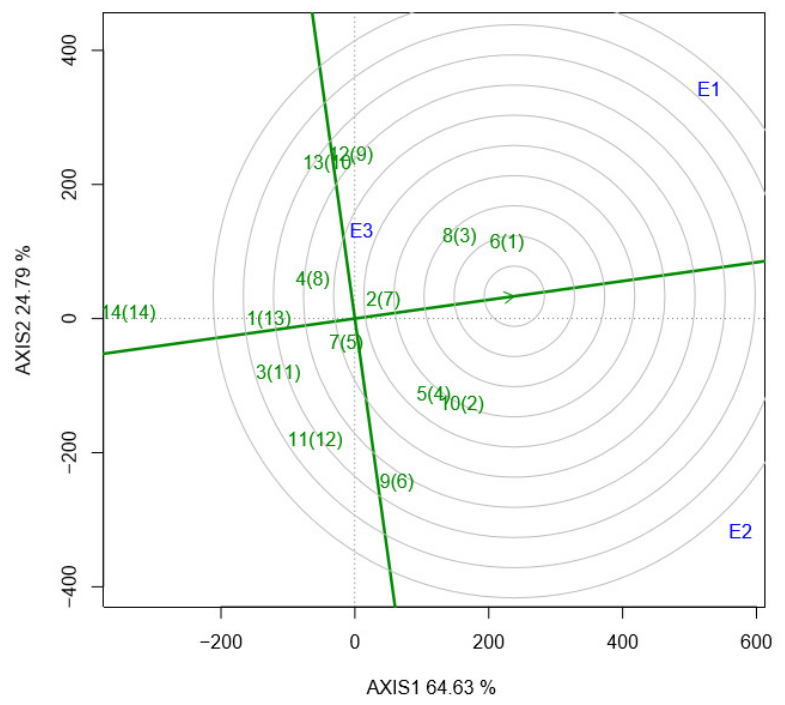

Figure 4. GGE-Biplot graph ("ideal genotype") for the grain yield of cowpea genotypes. * $\left(n^{\circ}\right)$ represents the cowpea yield ranking

According to Yan and Rajcan (2002), an ideal genotype should have consistently high average grain yield in all the environments in question, being graphically defined by the longest vector in PC1 and PC2 without projections, as shown by the arrow in the center of the concentric circles. According to Mattos (2012), a genotype is considered ideal if it has a high average yield and maintains this yield in all evaluated environments. Thus, even if this genotype is only an estimate, it is used as a reference for evaluating genotypes so that the most promising ones will be located as close as possible to it.

In Figure 5, each line connecting an environment to the Biplot origin is called environment vector. The environment E3 (Aquidauana, 2017) and E1 (Dourados, 2016) are positively correlated (acute angle), E3 (Aquidauana, 2017) and E2 (Dourados, 2017) are slightly negatively correlated (an obtuse angle), and E1 (Dourados, 2016) and E2 (Dourados, 2017) are uncorrelated (a right angle). The presence of obtuse 
angles is indicative of strong cross GxE interaction. In the visual analysis of the GGE-Biplot, the angles formed between the vectors of each environment are related to the correlation between the environments (YAN; TINKER, 2006).

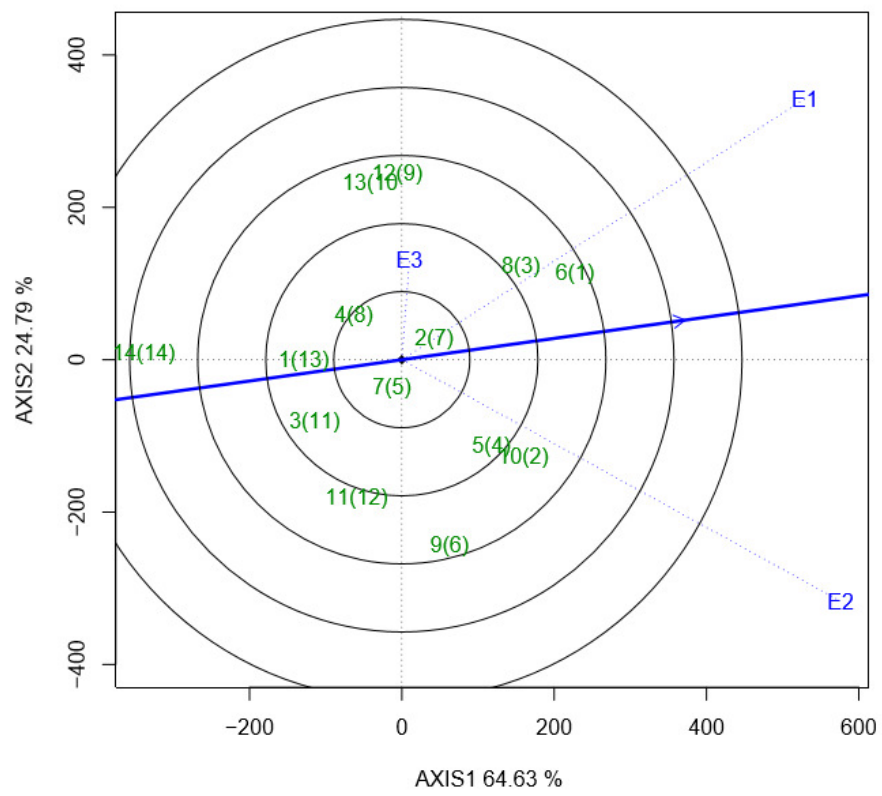

Figure 5. GGE-Biplot graph (“discrimination and representativeness”) for yield of cowpea genotypes. *(no) represents the cowpea yield ranking.

The concentric circles in the Biplot help to visualize the length of the environment vectors, which is proportional to the standard deviation within the respective environments and is a measure of the ability to discriminate environments. Therefore, of the three environments, E1 (Dourados, 2016) and E2 (Dourados, 2017) were more discriminating (more informative) and E3 (Aquidauana, 2017) the less discriminating.

Non-discriminating environments offer little information and hence should not be used as a test environment. Therefore, the E1 environment (Dourados, 2017) stood out in both modes of interpretation, thus being the "ideal" test environment for both discriminations of genotypes and representation of the environment. The evaluation of the test environment makes it possible to identify environments that can be used to select superior genotypes effectively for a mega environment. The selection of a test environment should show greater discrimination of genotypes and representativeness.

\section{Adaptability and stability via REML/BLUP}

The genotypes 6 (Pingo-de-ouro 1-5-4), 10 (Pingo-de-ouro 1-5-10) and 8 (Pingo-de-ouro 1-5-7) showed the best genotypic values for the mean of all environments (Table 6), where the genetic gains obtained from selection of them were, respectively: $12.45 \% ; 10.31 \%$ and 9.10 These values can be used as indicative for recommendation of these genotypes selected in other environments with GxE interaction pattern similar to the one verified in this study. In all three environments, the genotypes had the following mean genotypic value: $\mu=686.54$ in the three environments, where the mean genotypic value for the environments E1 (Dourados, 2016), E2 (Dourados, 2017) and E3 (Aquidauana, 2017) were $\mu 1=483.88, \mu 2=974.03$ and $\mu 3=601.70$, respectively.

Table 6. Genotypic mean for grain yield $\left(\mathrm{kg} \mathrm{ha}^{-1}\right)$ of cowpea genotypes for the three environments.

\begin{tabular}{cccccc}
\hline ID & Genotype & E1 & E2 & E3 & $\begin{array}{c}\text { Mean } \\
\left(\mathrm{kg} \mathrm{ha}^{-1}\right)\end{array}$ \\
\hline $\mathbf{1}$ & Bico-de-ouro 1-5-11 & 353.96 & 832.43 & 593.75 & 593.38 \\
$\mathbf{2}$ & Bico-de-ouro 1-5-15 & 564.48 & 987.74 & 511.25 & 687.83 \\
$\mathbf{3}$ & Bico-de-ouro 1-5-19 & 296.10 & 913.45 & 661.25 & 623.60 \\
$\mathbf{4}$ & Bico-de-ouro 1-5-24 & 432.33 & 891.34 & 728.75 & 684.14 \\
$\mathbf{5}$ & Pingo-de-ouro 1-5-26 & 555.40 & 1149.09 & 445.00 & 716.50
\end{tabular}


Adaptability and stability...

ABREU, H. K. A. et al.

$\begin{array}{cccccc}\mathbf{6} & \text { Pingo-de-ouro 1-5-4 } & 756.68 & 1181.01 & 771.25 & 902.98 \\ \mathbf{7} & \text { Pingo-de-ouro 1-5- 5 } & 426.85 & 998.69 & 678.75 & 701.43 \\ \mathbf{9} & \text { Pingo-de-ouro 1-5-8 } & 393.39 & 1185.69 & 513.75 & 697.61 \\ \mathbf{1 0} & \text { Pingo-de-ouro 1-5-10 } & 545.08 & 1240.31 & 642.50 & 809.29 \\ \mathbf{1 1} & \text { Pingo-de-ouro 1-5-11 } & 318.75 & 1006.90 & 488.75 & 604.80 \\ \mathbf{1 2} & \text { Pingo-de-ouro 1-5-14 } & 652.06 & 807.21 & 590.00 & 683.09 \\ \mathbf{1 3} & \text { BRS Tumucumaque } & 602.12 & 781.10 & 615.00 & 666.07 \\ \mathbf{1 4} & \text { BRS Imponente } & 145.09 & 598.48 & 602.50 & 448.69 \\ \text { Mean } & & 483.88 & 974.03 & 601.70 & 686.54\end{array}$

E1 = Dourados (2016); E2 = Dourados (2017); E3 = Aquidauana (2017).

The genotypes 6 (Pingo-de-ouro 1-5-4), 10 (Pingo-de-ouro 1-5-10) and 8 (Pingo-de-ouro 1-5-7) acquired the best genotypic values across the environments and for the average environment, according to the REML/BLUP (Table 7). According to MHPRVG, these same genotypes also obtained the best values, which simultaneously selects genotypes with high grain yield, adaptability and stability, although they do not report on the most similar sites. In this context, it is important to emphasize that there was an agreement of $80 \%$ between the GGE-Biplot and REML/BLUP methods for discriminating the best genotypes, a result also observed by Silva et al. (2011) and Santos et al. (2016).

Table 7. Adaptability and stability of genotypic values (MHPRVG) predicted by REML/BLUP for grain yield (kg ha-1) of 14 cowpea genotypes for each testing environment.

\begin{tabular}{ccccccc}
\hline ID & Genotype & E1 & E2 & E3 & $\begin{array}{c}\text { Average } \\
\text { environment }\end{array}$ & MHPRVG \\
\hline $\mathbf{1}$ & Bico-de-ouro 1-5-11 & 415.73 & 902.41 & 569.80 & 644.51 & 624.26 \\
$\mathbf{2}$ & Bico-de-ouro 1-5-15 & 508.25 & 978.51 & 575.22 & 687.11 & 688.02 \\
$\mathbf{3}$ & Bico-de-ouro 1-5-19 & 408.12 & 936.07 & 599.44 & 658.14 & 637.66 \\
$\mathbf{4}$ & Bico-de-ouro 1-5-24 & 467.80 & 948.69 & 638.70 & 685.45 & 685.81 \\
$\mathbf{5}$ & Pingo-de-ouro 1-5-26 & 514.64 & 1035.55 & 564.62 & 700.05 & 699.00 \\
$\mathbf{6}$ & Pingo-de-ouro 1-5-4 & 633.58 & 1104.16 & 720.70 & $\mathbf{7 8 4 . 1 7}$ & $\mathbf{8 3 0 . 2 3}$ \\
$\mathbf{7}$ & Pingo-de-ouro 1-5- 5 & 471.65 & 986.07 & 629.31 & 693.25 & 693.51 \\
$\mathbf{8}$ & Pingo-de-ouro 1-5-7 & 591.12 & 1033.91 & 629.08 & $\mathbf{7 3 4 . 1 5}$ & $\mathbf{7 5 8 . 0 0}$ \\
$\mathbf{9}$ & Pingo-de-ouro 1-5-8 & 460.49 & 1040.44 & 579.06 & 691.53 & 680.63 \\
$\mathbf{1 0}$ & Pingo-de-ouro 1-5-10 & 540.98 & 1092.08 & 652.73 & $\mathbf{7 4 1 . 9 1}$ & $\mathbf{7 6 0 . 5 2}$ \\
$\mathbf{1 1}$ & Pingo-de-ouro 1-5-11 & 408.89 & 957.88 & 542.21 & 649.66 & 622.24 \\
$\mathbf{1 2}$ & Pingo-de-ouro 1-5-14 & 532.77 & 923.35 & 597.12 & 684.98 & 693.29 \\
$\mathbf{1 3}$ & BRS Tumucumaque & 512.53 & 910.19 & 599.16 & 677.30 & 682.33 \\
$\mathbf{1 4}$ & BRS Imponente & 307.79 & 787.00 & 526.53 & 579.24 & 521.09 \\
Mean & & 483.88 & 974.02 & 601.69 & 686.53 & ---- \\
\hline
\end{tabular}

The values presented for MHPRVG were computed, already penalizing the genotypes for the instability across the sites and, at the same time, capitalizing the capacity of response (adaptability) to the improved environment (RESENDE, 2007; MAIA, 2009). However, the identification of stable and high-yielding genotypes among the different environments is still a challenge for breeders, and it is evident that the use of different methods for specifying stability and adaptability will provide reliable recommendations regarding superior genotypes.

\section{CONCLUSIONS}

GGE-Biplot

and

REML/BLUP methodologies are concordant for identifying superior cowpea genotypes for the State of Mato Grosso do Sul.

The genotypes 6 (Pingo-de-ouro 1-5-4), 10 (Pingo-de-ouro 1-5-10) and 8 (Pingo-de-ouro 1-5-7) are the most suitable to be grown in the State, because they have gathered high grain yield, adaptability and stability. 
RESUMO: Diversas metodologias têm sido propostas com o intuito de estimar a influência que a interação genótipos $\mathrm{x}$ ambientes exerce sobre os vários caracteres de interesse. Dentre estes modelos mistos via REML/BLUP e GGE-Biplot têm se destacado para identificar genótipos superiores e estratificas ambientes. O uso de informações ambientais pode ser útil para encontrar os fatores que estão na real diferença entre os genótipos. O objetivo deste estudo foi comparar metodologias estatísticas para a análise da adaptabilidade e estabilidade de genótipos de feijãocaupi em ensaios de valor de cultivo e uso. Os experimentos foram realizados no período de Março a Julho de 2016 e 2017, nos municípios de Dourados e Aquidauana, sendo dois anos em Dourados e um ano em Aquidauana. Foi utilizado o delineamento experimental blocos casualizados, com 14 genótipos e quatro repetições, sendo 12 linhagens avançadas e duas cultivares comerciais. Depois de detectar a interação significativa entre genótipos e ambientes, a adaptabilidade e a estabilidade fenotípica dos genótipos de feijãocaupi foram analisadas pelos métodos GGE-Biplot e REML/BLUP. Os dois métodos foram concordantes em $80 \%$ na identificação dos melhores genótipos de feijão-caupi para o Estado de Mato Grosso do Sul. Os genótipos Pingo-de-ouro 1-5-4, Pingo-de-ouro 1-5-10 e Pingo-de-ouro 1-5-7, foram os genótipos que apresentaram simultaneamente alta produtividade de grãos, adaptabilidade e estabilidade, sendo assim indicados para o cultivo no Mato Grosso do Sul.

PALAVRAS-CHAVE: Vigna unguiculata. Interação genótipos $\times$ ambientes. Análise multivariada. Modelos mistos.

\section{REFERENCES}

BARROSO, L. M. A.; TEODORO, P. E.; NASCIMENTO, M.; TORRES, F. E.; DOS SANTOS, A.; CORRÊA, A. M.; SAGRILO, E.; CORRÊA, C. C. G.; SILVA, F. A.; CECCON, G. Bayesian approach increases accuracy when selecting cowpea genotypes with high adaptability and phenotypic stability. Genetics and Molecular Research, Ribeirão Preto, v. 15, p. 1-11, 2016. https://doi.org/10.4238/gmr.15017625

CARDOSO, P. C.; BRONDANI, C.; MENEZES, I. P.; VALDISSER, P. A. Discrimination of common bean cultivars using multiplexed microsatellite markers. Genetics and Molecular Research, Ribeirão Preto, v. 13, p. 1964-1978, 2014. https://doi.org/10.4238/2014.March.24.1

CORNELIUS, P. L.; CROSSA, J.; SEYEDSADER, M. S. Statistical test and estimators of multiplicative models for genotype-by-environment interaction. In: KANG, M. S.; GAUCH, H. G. (Ed). Genotype-byenvironment interaction. Boca Raton: CRC Press, 1996. P. 199-234.

https://doi.org/10.1201/9781420049374.ch8

CROSSA, J.; CORNELIUS, P. L. Sites regression and shifted multiplicative model clustering of cultivar trial sites under heterogeneity of error variances. Crop Science, Madison, v. 37, p. 405-415, 1997. https://doi.org/10.2135/cropsci1997.0011183X003700020017x

CRUZ, C. D.; REGAZZI, A. J.; CARNEIRO. Modelos biométricos aplicados ao melhoramento genético. 4. ed. Viçosa: UFV, 2006. 390 p.

GABRIEL, K. R. The Biplot graphic display of matrices with application to principal component analysis.

Biometrika, London, v. 58, n. 3, p. 453-467, 1971. https://doi.org/10.1093/biomet/58.3.453

KARIMIZADEH, R., MOHAMMADI, M., SABAGHNI, N., MAHMOODI, A. A., ROUSTAMI, B., SEYYEDI, F. E AKBARI, F. (2013). GGE Biplot analysis of yield stability in multienvironment trials of lentil genotypes under rainfed condition. Notulae Scientia Biologicae, v. 6, p. 256-262.

https://doi.org/10.15835/nsb529067

MAIA, M. C. C.; RESENDE, M. D. V.; PAIVA, J. R.; CAVALCANTI, J. J. V.; BARROS, L. M. Seleção simultânea para produção, adaptabilidade e estabilidade genotípicas em clones de cajueiro, via modelos misto. Pesquisa Agropecuária Tropical, Goiânia, v. 39, p. 43-50, 2009. 
MARTINELLI, A. P. Métodos AMM, GGE biblot, REML/BLUP e Análise de Fatores na estabilidade e estratificação de ambientes de safrinha para seleção de híbrido de milho. 2013. 61p. Dissertação (Mestrado) - Universidade Federal de Uberlândia, Uberlândia, Minas Gerais, Brasil.

MATTOS, P. H. C. de. Adaptabilidade e estabilidade de genótipos precoces de cana-de-açúcar no Estado do Paraná pelos métodos AMMI e GGE Biplot adaptabilidade e estabilidade de genótipos precoces de cana-deaçúcar no Estado do Paraná. 2012. 42 p. Dissertação (Mestrado em Produção Vegetal) -

Universidade Federal do Paraná, Curitiba, 2012.

OLIVEIRA, L. A.; SILVA, C. P.; TEODORO, P. E.; TORRES, F. E.; CORRÊA, A. M.; BHERING, L. L. Performance of cowpea genotypes in the brazilian midwest using the bayesian additive main effects and multiplicative interaction model. Agronomy Journal, Madson, v. 110, p. 147-154, 2018. https://doi.org/10.2134/agronj2017.03.0183

PEREIRA, H. S.; DEL PELOSO, M. J.; BASSINELLO, P. Z.; GUIMARÃES, C. M. Genetic variability for iron and zinc content in common bean lines and interaction with water availability. Genetics and Molecular Research, Ribeirão Preto, v. 13, p. 6773-6785, 2014. https://doi.org/10.4238/2014.August.28.21

R DEVELOPMENT CORE TEAM (2014). R: A language and environment for statistical computing. Disponível em: <http://www.R-project.org >. Acessado em 23 outubro de 2017.

RESENDE, M. D. V. SELEGEN-REML/BLUP: sistema estatístico e seleção genética computadorizada via modelos lineares mistos. Colombo: Embrapa Florestas, 2007. 359p.

RODRIGUES, E. V.; DAMASCENO-SILVA, K. J.; ROCHA, M. M.; BASTOS, E. A.; TEODORO, P. E. Selection of cowpea populations tolerant to water deficit by selection index. Revista Ciência Agronômica, Fortaleza, v. 48, p. 889896, 2017. https://doi.org/10.5935/1806-6690.20170105

ROSADO, A. M., ROSADO, T. B., ALVES, A. A., LAVIOLA, B. G.; BHERING, L. L. (2012). Seleção simultânea de clones de eucalipto de acordo com produtividade, estabilidade e adaptabilidade. Pesquisa Agropecuária Brasileira, 47, 964-971. https://doi.org/10.1590/S0100-204X2012000700013

SANTOS, A.; CECCON, G.; TEODORO, P. E.; CORREA, A. M.; ALVAREZ, R. C. F.; SILVA, J. F.; ALVES, V.B. Adaptabilidade e estabilidade de genótipos de feijão caupi ereto via REML/BLUP e GGE Biplot. Bragantia, Campinas, 2016.

SANTOS, J. A. S., SOARES, C. M. G., CORRÊA, A. M., TEODORO, P. E., RIBEIRO, L. P. E ABREU, H. K. A. Agronomic performance and genetic dissimilarity among cowpea (Vigna unguiculata (L.) Walp.) genotypes. Global Advanced Research Journal of Agricultural Science, Cidad do Cabo, v. 3, p. 271-277, 2014.

SILVA, G. O., CARVALHO, A. D. F., VEIRA, J. V. E BENIN, G. Verificação da adaptabilidade e estabilidade de populações de cenoura pelos métodos AMMI, GGE Biplot e REML/BLUP. Bragantia, Campinas, v. 70, p. 494- 501, 2011. https://doi.org/10.1590/S0006-87052011005000003

TEODORO, P. E.; BARROSO, L. M. A.; NASCIMENTO, M.; TORRES, F. E.; SAGRILO, E.; SANTOS, A.; RIBEIRO, L. P. Redes neurais artificiais para identificar genótipos de feijão-caupi semiprostrado com alta adaptabilidade e estabilidade fenotípicas. Pesquisa Agropecuária Brasileira, Brasília, v. 50, p. 1054-1060, 2015. https://doi.org/10.1590/S0100-204X2015001100008

TORRES, F. E.; TEODORO, P. E.; CARGNELUTTI FILHO, A.; SANTOS, A.; ROCHA, M. M.; SAGRILO, E. Adaptability and phenotypic stability of semi-prostate cowpea genotypes in Mato Grosso do Sul. Bioscience Journal, Uberlândia, p. 1435-1441, 2016. https://doi.org/10.14393/BJ-v32n6a2016-32813 
YAN, W.; KANG, M. S. GGE Biplot analysis: a graphical toll for breeders, geneticists, and agronomists. 1.ed. Boca Raton: CRC Press LLC, 2003. 288p. https://doi.org/10.1201/9781420040371

YAN, W.; TINKER, N. A. Biplot analysis of multi-environment trial data: principles and applications.

Canadian Journal of Plant Science, Ontario, v. 86, n. 3, p. 623-645, July 2006. https://doi.org/10.4141/P05169

YAN, W. E RAJCAN, I. (2002). Biplot evaluation of test sites and trait relations of soybean in Ontario. Crop Science, 42, 11-20.

YAN, W. GGE Biplot vs. AMMI graphs for genotype-by-environment data analysis. Journal of the Indian Society of Agricultural Statistics, New Delhi, v. 65, n. 2, p. 181-193, 2011.

https://doi.org/10.2135/cropsci2002.0011

https://doi.org/10.2135/cropsci2002.1100

YAN, W.; HUNT, L.A.; SHENG, Q.; SZLAVNICS, Z. Cultivar evaluation and mega-environment investigation based on the GGE Biplot. Crop Science, Madison, v. 40, n. 3, p. 597-605, 2000.

https://doi.org/10.2135/cropsci2000.403597x

YAN, W.; KANG, M.S.; MA, B.; WOODS, S.; CORNELIUS, P. L. GGE Biplot vs. AMMI Analysis of Genotype-by-Environment Data. Crop Science, Madison, v.47, p.643-653, 2007.

https://doi.org/10.2135/cropsci2006.06.0374 